\title{
Access to Collective Litigations in China: A Tough Work
}

\author{
Jun Xie (Corresponding author) \\ School of Law, Renmin University of China \\ Pingyuan Si 417, Renmin University of China, Haidian District, Beijing 100872, China \\ E-mail: June303@sina.com
}

Lijuan Sun

School of Law, Renmin University of China

Pingyuan Si 418, Renmin University of China, Haidian District, Beijing 100872, China

E-mail: sunlijuan008@tom.com

\begin{abstract}
Since the legislation of the China's 1991Civil Procedure Law (CPL), which explicitly permits three types of collective actions, multi-plaintiff groups have brought suits seeking compensation. With the high tempo in economy and the social reform, disputes related to collective parties arise rapidly, class rushes to China's courtrooms. The increasing number of collective actions is one of the remarkable aspects of the civil litigation explosion in resent years in China. Series of "Judicial Interpretations" issued by the Supreme People's Court (SPC) which show SPC's hostile attitude to the collective litigation have triggered the fire among the scholars. To release heavy pressure in the collective litigation, the SPC and the local courts turn to alternative resolutions, such as the mediation and the test case device. Attention should be paid to the SPC's policies and their impact to the multi-plaintiff disputes so as to get a deep understanding about the collective litigation in China. The purpose of this article is to set forth that claimants' access to collective litigation a very tough work under the SPC's policies and other related guidelines.
\end{abstract}

Keywords: Collective Litigation, Judicial Policy, Alternative Resolutions

\section{Introduction}

As it is in many countries, collective and representative actions have always received much attention, not only from the legislators but also from the courts. Since the legislation of the China's 1991Civil Procedure Law (CPL), which explicitly permits three types of collective actions, multi-plaintiff groups have brought suits seeking compensation for their damage caused by mass tort or breach of contract. With the high tempo in economy and the social reform, disputes related to collective parties arise rapidly, class rush to China's courtrooms, especially with the fast developing securities market since 2000. The increasing number of collective actions is one of the remarkable aspects of the civil litigation explosion in resent years in China. The anniversary report in Mar. 9, 2005 by the president of the Supreme Court stated that the number of the collective suits has reached to 538,941, increased by $9.5 \%$ comparing with 2004 . Series of "Judicial Interpretations" issued by the Supreme People's Court (SPC) are focused on the collective and representative litigation. These interpretations or other kinds of normative guidance by the SPC are binding on all courts across China, which show the judicial policies of the SPC on dealing with collective disputes. And such policies have been the subject of intense debate among the scholars.

To release heavy pressure in the collective litigation, the SPC and the local courts turn to alternative resolutions. Attention should be paid to the SPC's policies and their impact so as to get a deep understanding about the collective litigation in China. The purpose of this article is to set forth the SPC's policies and other related guidelines make the claimants' access to collective litigation a very tough work. This article is divided into five parts: Part I provides a brief statutory outline of the collective and representative actions in China. Part II provides an overview of the judicial policy from the SPC. The primary attitude of the SPC is that, collective litigation should be restricted. Part III outlines the role of the lawyer in the resolving the collective disputes; legal aid and judicial aid are presented too. Part IV analyses Chinese scholars have fierce debate over the SPC's policies. Part V gives a overall introduction on the development of the alternative disputes resolutions from the practical point of view with some typical cases. Lastly, the article concludes with a brief comment on the judicial policy and the importance of the collective litigation to the society.

\section{A brief statutory outline}

While Chinese civil procedure law has its deepest roots in the continental law tradition, common law influences are also 
increasingly evident. In terms of forms of collective litigation, China has borrowed from both the Japanese type of representative action (Art. 54, CPL) and the US model of class action (Art. 55, CPL). Under the CPL, there are broadly three types of "collective litigations". These are: " non-representative group litigation" (gongtong susong), "representative group litigation in which the number of litigants is fixed" at the time the case is filed (renshu queding de daibiaoren susong), and "representative group litigation in which the number of litigants is not fixed" at the time the case is filed (renshu bu queding de daibiaoren susong).

\section{1 "Non-representative group litigation" (Art. 53, CPL)}

The non-representative form of collective litigation under Art. 53 CPL originates from Art. 47 of the 1982 CPL, which governed the non-representative form of collection action. Under Art. 53, in the case of the common question of law or fact, and the number of the plaintiffs or the defendants exceed 2, the court should join the parties if they agree. The burden of managing the procedure is heavy if the number of the party reach to hundreds and thousands. In the late 1980s, courts in China faced an increasing number of multiparty disputes, and the mechanism was soon found not to be inadequate to handle collective dispute (Jiang Wei and Jia Changcun, 1989, P.103, 110). The lack of alternative formal procedures in the $1982 \mathrm{CPL}$ posed a challenge to the Chinese courts. Reform was needed to deal with the mass disputes litigation effectively. Some courts used procedures resembling representative actions later included in the CPL 1991 to deal with some of more complex disputes that came before them. The famous "An Yue Rice-Seed Case" (Anyue Zhongzi An) was the very beginning.

The "An Yue Rice-Seed Case" is one of the successful litigation which the court used representative procedure to solve a multiparty dispute. In that case, 1,569 Sichuan farmers brought an action before a Basic People's court in order to compensate their loss in a seed contract. The court permitted the plaintiff as a class to select eight representatives to carry out the specific work through the procedure for the class (SPC GAZETTE, No. 3, 1986). Since then, cases handled in similar fashion were reported (Jiang Wei and Jia Changcun, 1989, P.110, 111). The SPC authorized the use of representative litigation in some of its opinions, such as "Opinions of the SPC on several issues regarding the hearing of Village Assignment Contract Dispute Cases (Zuigao Renmin Fayuan Guanyu Shenli Nongcun Chengbao Hetong Jiufen Anjian Ruogan Wenti De Yijian)", "Response of the SPC regarding Some Questions Connerning the Specific Use of the Economic Contract Law in the Judging of Economic Contract Dispute Cases (Zuigao Renmin Fayuan Guanyu Zai Shenli Jingji Hetong Jiufen Anjian Zhong Juti Shiyong Hetong Fa De Rougan Wenti De jieda)".

Considering the growth in number and scale of multiparty disputes in China, the need for a more efficient mechanism than the Art. 53, and the successful judicial experience in certain collective litigations, the Chinese legislators decided in 1991 to introduce representative forms for collective disputes, which resulted in the Art. 54 and 55, CPL.

\subsection{Representative Group litigation under Art 54, CPL (renshu queding de daibiaoren susong)}

Art 54 of the CPL governs group litigation suits in which the number of litigants on either side of the party is "large" and fixed at the time the suit is filed. The litigants on each side may select a certain number of representatives (leading plaintiffs) to carry out the procedure. The SPC, in "Opinion on Severl Issues Regarding the Implementation of the Civil Procedure Law of the People's Republic of China,"(1992 SPC Opinion)(Zuigao Renmin Fayuan Guanyu Shiyong Zhongguo Renmin Gongheguo Minshi Susong fa Ruogan Wenti De Yijian) defines "large" generally to be ten or more persons (Art. 59, 1992 SPC Opinion). Two or five representatives may be selected (Art. 62, 1992 SPC Opinion). For those who fail to select a representative, they are permitted to join the litigation on their own name in the case of essential joint litigation (biyao gongtong susong), or file individual independent claim in the case of ordinary joint litigation (putong gongtong susong) (Tang Dehua, 1991, P.105).

Representatives are on behalf of themselves and those who select them, and the class judgment has a binding effect on the represented parties (Art. 54, CPL). Under Art. 54, almost every procedural decision made by the representative has the binding effect on the class. However, major decisions disposing the class's substantial rights should be approved by the represented parties in advance. These decisions include the change of the representative, abandoning the claims, acceptance of the counter claims from the opposing side, and settlement (Art. 54, CPL).

\subsection{Representative Group litigation under Art 55, CPL (renshu bu queding de daibiaoren susong)}

China's highest legislative body, the National People's Congress (NPC)'s decision in Art 55 in 1991 CPL, which models the US type of class action (Jiang Wei and Xiao Jianguo, 1994, P.3,4), came as a surprise to many Chinese scholars (Zhang Weiping, 2000, P. 362,363). Some believe that Chinese legislators acted in haste, without enough argumentation, and that the Art 55 is in counter to the Chinese continental law tradition (Fan Yu, 2005, P. 25.26).

As the number of parties is not fixed at the time the case is filed, the court may issue a notice about the question of law or fact to the litigation, and instructing all persons who have the common question of law or fact to register within a specific period (Art. 55, CPL). The length of the period may not be less than 30 days (Art 63, 1992 SPC Opinion).

Potential participants who seek to register will have to demonstrate to the court that they have common questions of law 
or fact. Those failing to register in time will not be permitted to join the class, but they are not prevented from bring their own litigation (Art 64, 1992 SPC Opinion).

All the registered plaintiffs may select representatives as leading plaintiffs to carry on the litigation (Art 55, CPL). If they fail to appoint any representatives, the court may nominate representatives after consultation with the registered parties (Art 61, 1992 SPC Opinion). Restriction to the representatives' procedural rights are resemble to Art. 54 CPL (Art 55, CPL).

The court's decision is binding on all those who have registered and on those who do not join the class but bring similar claims within "the limitation of the action" (Art 55, CPL).

\section{Judicial Policy}

Facing with the increasing collective disputes in China, the SPC has developed a set of rules governing the multiparty litigation. And the SPC starts from the private securities litigation arising from false statements on China's securities market. The series of judicial rules triggered the intensive academic debate, and scholars once again focus their eyes on the collective litigation and the SPC's judicial policy in it.

On 20 September 2001, 363 aggrieved investors of the Yorkpoint Science \& Technology Co. (Yi An Keji Gufen Youxian Gongsi), a Chinese listed company notorious for its large-scale market manipulation, simultaneously filed lawsuits with Intermediate People's Courts in Beijing, Shanghai and Guangzhou. The next day the SPC issued a notice, "Notice on Temporarily Not to Accept Secritities Related Civil Compensation Cases" (2001 Notice) (Guanyu She Zhengquan Minshi Peichang Anjian Zan Bu Shouli De Tongzhi) promulgated on Sep. 21, 2001, explaining that People's Courts were not ready for accepting the securities litigation concerned with false statements, manipulation, fraud and insider dealing, and instructing lower courts temporarily not to accept private securities lawsuit. Justice Li Guoguang, then drafter of 2001 Notice, justified the SPC's refusal to the securities litigation on the grounds that the Chinese security market then was weak, it needed a stable circumstance for further development, that the new arising securities problems needed to be settled step by step, surely litigation couldn't get the problems solved once for ever, and that Chinese judges lacked the judicial resources and knowledge to adjudicate such case (Li Guoguang and Jia Wei, 2003, P. 2, 3). However, the 2001 Notice received severe criticism from academics, practitioners and investors, saying that the SPC's policy unfairly blocked the stockholders' access to the justice (Jiang Wei, 2005, P. 113, 114).

Facing mounting pressure, on 15 January 2002 the SPC partially lifted the temporary ban. It issued a second notice "Notice on Relevant Issues Concerning Accepting Civil Tort Dispute Cases Caused by False Statement on the Securities Market" (2002 Notice) (Guanyu Shouli Zhengquan Shichang yin Xujia Chenshu Yinfa de Minshi Qinquan Jiufen Anjian Youguan Wenti de Tongzhi), allowing lower courts to accept private securities suits against the false statements only. Other unlawful behaviors in the securities market are still rejected from the courts. Three days later, shareholders in the Daqing Liangyi Co., a listed company involved in fraudulent disclosure scandals, took the lead in a race triggered by 2002 Notice to sue listed companies. Harbin Intermediate People's Court accepted the Daqing Lianyi Case on 24 January. By 28 March over 700 investors had filed suit. Harbin People's Court asked the plaintiffs divided into several units, 10 or 20 persons at most in each, or else refused hearing (Zhang Wusheng and Yang Yanyan, 2007). Within a year, according to the Michael Palmer, the Chinese courts had accepted nearly 900 cases in which investors sought damages from listed companies that allegedly made false disclosures (Michael Palmer and Chao Xi, 2007).

About one year after 2002 Notice, the SPC eventually on December 26, 2002 issued another judicial interpretation for the lower courts to handle the collective securities compensation, "Several Provisions on Hearing Civil Compensation Cases Caused by False Statements on the Securities Market"(2002 Provisions)(Guanyu Shenli Zhengquan Shichang yin Xujia Chenshu Yinfa de Minshi Peichang Anjian de Ruogan Guiding). Both 2002 Notice and 2002 Provisions ruled out the use of Class Action (jituan susong) - the CPL Art 55 type of representative litigation - as a mechanism for collective securities disputes arising from false disclosures (Li Guoguang and Jia Wei, 2003, P. 295, 296). The SPC's strong preference for CPL Art 54 Style of representative litigation has been explicitly expressed. According to 2002 Provisions, the court may require individual claimants to join collective litigation arising from the same false disclosure, and order a merger of several collective litigations into a single one if conditions are fixed (Art. 13, 2002 Provisions). The power of the court significantly expands as the court can divide or merger into a collective case, for the sake of connivance in managing the litigation. The plaintiff had to join the unit other wise, the claim would not accept, Daqin Lianyi Case showed.

Another noticeable SPC's policy is "Notice on Accepting Group Litigation" (2006 Notice) (Guanyu Renmin Fayuan Shouli Gongtong Susong Anjian Wenti de Tongzhi) on 1 Jan. 2006. 2006 Notice emphasizes that Basic People's Courts should be the major bodies to handle the collective suits, only when in special circumstance and approved by the SPC should the Higher People's Courts accept the collective litigation (Art. 1, 2006 Notice). The courts can accept the case individually if not suitable in collective litigation mechanism (Art. 1, 2006 Notice). The SPC's effort to lower the level of the court is to "nip the collective disputes in the bud", according to the drafter of 2006 Notice (Ji Min, 2006, P. 
14-16). Articles criticizes that 2006 Notice gives the representative litigation a deathblow. The representative litigation which has already been used hardly is going to receive inhospitality from the courts (Zhang Wusheng and Yang Yanyan, 2007, P.118). From 2002 Provisions to 2006 Notice, the SPC's attitude is clearly showed: the scale of collective litigation should be reduced to as small as possible, individual suit is always better than the collective one. As higher level of the courts may bring more negative impact to the society, Basic People's Courts should make every possible effort to settle the collective litigation (Art. 4, 2002 Provisions).

\section{Tightly Strict With the Legal Profession}

Not only the hostile policies from the SPC but also the tightly control of the legal profession and other sort of aid that add the difficulty to the litigants' access to the collective actions.

\subsection{Legal Profession: Restricted}

With the rise of collective litigations is the rapid growth of the Chinese legal profession too. Collective litigations are almost certain to increase incentives for lawyers to undertake difficult cases. However, the strength of such incentives will depend both on the control over the lawyers' participation in multiparty cases and on China's regulation of lawyer's fees.

\subsubsection{Control of the Legal Profession}

So far the Chinese government has maintained tight control over the lawyers participating in multiparty cases. In April 2006, the National China Lawyers' Association, a government-backed regulatory body of Chinese lawyers, promulgated guideline "National China Lawyers' Association Guiding Opinions on Lawyers Handling Mass Suits" (Guilding Opinions) (Zhonghua Quanguo Lüshi Xiehui Guanyu Lüshi Banli Quntixing Anjian Zhidao Yijian) instructing lawyers on how to handle "mass suits"(quntixing anjian). In principle, lawyers should play a supervisor role in representing group litigations (Art. 1(3), Guilding Opinions). Lawyers are required to report to the responsible government agencies, should they find that the clients they represented are likely to take a course of action threatening "social stability" (Art. 2, Guilding Opinions). Lawyers should be well cautious to if there is any connection with overseas organizations and foreign media during collective litigation procedure (Art. 2, Guilding Opinions). There are other procedural burdens for participating lawyers and their firms (Art. 3, Guild). In one word, lawyers are restricted to the collective cases.

\subsubsection{Lawyers' Fees}

The above guideline is not the only regulation that makes the lawyers under strict control. They are bind to the regulations on the Lawyers fee. Firstly, party has to afford his own lawyer's fee even in the collection litigation, which is different from the U.S. style class action that the lawyer's fee can be asked to be paid by the loser. Plaintiffs can not afford lawyers in most cases, not alone in the collective litigation that claims for little but pay much for success. Secondly, contingency fee in collective cases is explicitly forbidden since the promulgation of "Supervisory Measures on Lawyers Services Fees" (2006 Supervisory Measures) (Lüshi Fuwu Shoufei Guanli Banfa) in 2006. Before that, contingency fee arrangements have operated unofficially in China for many years. It is reported that the range of the contingency fee percentage is from $10 \%$ to $40 \%$, or even as high as $50 \%$ of the recovery. An well-known example is the Daqing Lianyi Case, in which a group of lawyers headed by a prominent shareholder activist, Prof. Guo Feng, represented a large number of injured investors on a "no win, no pay" agreement. The counsel finally reaped $20 \%$ of the net recovery as contingency fee (Michael Palmer and Chao Xi, 2007).

While the contingency fee connects the interest of the group and its counsel together, thus keeping the lawyer acting diligently and helping parties accessing to justice (Linda Silberman, 1999, P.201), unfortunately, contingency fee arrangements is no longer available under 2006 Supervisory Measures.

Though facing with many impediments, recent collective actions, such as the "Sanlu Milk Powder Case" (Sanlu Naifen An) may suggest a shifting role for lawyers as they are drawn to cases with potentially large social impacts. Since the disclosure by media of the melamine Sanlu Milk Powder, lawyers from all around China are ready to help for free. According to the "Briefing of the Volunteer Lawyers in Sanlu Milk Powder Case" (the Briefing) (Sanlu Naifen Shijian Zhiyuan Lüshituan Gongzuo Jianbao), until September 27, 2008, the total number reached to 124 within 22 provinces, and the number is increasing. At the night of September 18, 2008, 18 volunteer lawyers in Beijing had a meeting discussing plans for further legal aid. That the volunteer lawyers' success in helping the victims in Sanlu Milk Powder Case has once again called for recognition of the role of the lawyer in law enforcement. Unlike U.S legal profession, who act as a bounty hunter in class action obtain nearly 30\% of the recover(Theodore Eisenber and Geoffrey P. Miller, 2004, P. 27, 51-54), the increased willingness of Chinese lawyers to challenge powerful local entities suggests that increased involved in collective litigation may help to accelerate the development of a more independent legal profession. Meanwhile the lawyers' endeavors in the collective cases may help the China building a law-bases society too: lawyer-represented collective cases may force local governments or industries to obey national laws (Deorah R. Hensler, 1999, P.20). Collective litigations suggest that lawyers may be assuming more active position in the project of law implementation (Benjamin Liebman, 1998). 


\subsection{Legal Aid}

China has developed a nationwide formal legal aid system, providing free legal assistance to economically disadvantaged citizens (Benjamin Liebman, 1999). Most legal aid programs have established by the Ministry of Justice and local justice bureaus, and are funded mainly by the government, in a few cases, the Ford Foundation. Under the "Regulations on Legal Aid" (2003 Regulation) (Falü Yuanzhu Tiaoli), those have low incomes may apply for legal aid under six circumstances (Art. 10, 2003 Regulation). Whether parties in collective suits are entitled to the legal aid is unclear. Theoretically legal aid is likely to be offered to the multiparty suits, if they fall into those six circumstances. However, it seems that plaintiffs in collective litigation have only limited access to legal aid. For one thing, many local administrative departments set a very low maximum income eligibility level for legal aid, and only a small fraction of the population living in extreme poverty is eligible for legal aid. A large number of people are not eligible for legal aid neither can they afford to pay for their own lawyers. In addition, legal aid providers tend to lack independence. Government-funded aid centers would probably not provide legal aids to collective actions against a government-related defendant, for example, a powerful local state-owned enterprise, or a big land agent.

\subsection{Judicial Aid}

China has developed a so-called "Judicial Aid" (sifa jiuji) system alongside the legal aid system. According to the "Measures on Litigation Fees" (2006 Measures) (Susong Shoufei Banfa), Chinese courts provide financial aid — in form of full or partial remission of court fees (Art. 4, 2006 Measures). There are reported collective suits in which Chinese local courts exempted the claimants from paying the court fees, for example, a group of 73 claimants who were victims in a chemical explosion incident got such judicial aid. In addition, the court fee is halved if the case is concluded by mediation.

The above analysis shows that, while contingency fee arrangements is prohibited in collective litigations, litigants are not guaranteed to access to justice sufficiently from current legal aid projects and judicial aid schemes. Collective litigants may have to find other solutions to protect their rights whether they like it or not.

\section{Critiques and analysis}

Generally speaking, most researchers are critical to the SPC's policy on the collective litigation. In a frequently quoted article, the author speaks high of the representative litigation in CPL, pointing out that it is one of the most successful mechanisms adapting merits of foreign collective litigation with consideration of Chinese parties' inability and reluctance to use the courts (Fu Yulin, 2002). The representative litigation in CPL is perfect both from the theoretical and feasible point of view. Prof. Fu further analyses the reasons why such mechanism isn't used as it should be in practice:

- Lacking of judicial independence, the courts are unable to handle collective disputes. Although facing with the dramatic increase in multiparty disputes and the needs for more judicial remedies from the justice, the People's Court in China has no enough resources to fulfill its duty to offer judicial products to the society. Historically, Chinese courts are dependent heavily on the government, especially the financial aspect, which makes the courts so "loyal" to government's policies or decision. The Courts have little voice in collective dispute litigation. The courts would like to choose not to accept the some sensitive cases and leave them to the government who the courts believe is strong enough to deal with the collective disputes. However, whether it is sensitive or not, is all up to the courts. Sometimes, local governments interfere with the courts' power in case acceptance. In some sensitive cases, local governments tried their best to give the courts pressure not to accept the cases, especially when the government departments are at stake.

- Irrational evaluation system brings the judge heavy pressure on his work. Theoretically, representative litigation may make litigation more economically feasible by allowing plaintiffs to pool their resources to hire counsel and cover litigation costs. Time and money could be saved. However, the Chinese courts follow an administrative supervision model, in which judge's work is appraised by the number of cases he has processed. The more cases he hears, the more he will be paid. Therefore, division of a collective litigation is a good choice. Meanwhile, representative litigation is time-consuming: judges must notify prospective group members, supervise the appointment of representatives, and if plaintiffs are successful, oversee the distribution of awards to large numbers of individuals. The enforcement of civil judgments is a tough job (Donald Clark, 1996, Vol. 10). Not to mention the collective litigation. As a result, many judges resist accepting class actions out of fear that the cases will be too complex.

Finally, Prof. Fu suggests that the government should leave more room for the court to increase its role of collective dispute resolution, and the court must prove itself in managing multiparty litigation — reject to accept the case can't be a good choice.

It's not until the publication of Group Litigation by Prof. Fan that the SPC's policy receive positive appraisal. The Group Litigation gives us totally fresh comments on the SPC's policy. Prof. Fan concludes that (Fan Yu, 2005, P.450.451), the representative litigation relies heavily on the judge's management. At present, China is not ready to adopt the US type of class action - the Chinese legislators acted in haste, with very limited ledge of possible problems 
with using Art $55 \mathrm{CPL}$. She emphasizes that, it's right and necessary for the SPC to take a negative policy towards the collective litigation. Although the Group Litigation doesn't justify the courts' rejection on collective claims, as far as the effect of the collective disputes resolutions is concerned, representative litigation is not the best choice in China either. The suitable way to deal with the collective action is the alternative dispute resolutions. In one well quoted paper, the author expresses strong disproval of Group Litigation, stating that the SPC's negative policies towards the collective cases are understandable but not acceptable, and that these policies result in the decrease of the status of the representative litigation in Chinese disputes resolution system. Because of such policies, People's Courts are not willing to accept multiparty cases without any lawful reasons, which harms the party's actio and runs counter to the CPL. The author believe that not the lack of judicial independence and court's own interest but the misunderstanding of the function of the representative litiagation is the real reason why the representative litigation is ignored in practice (Zhang Wusheng and Yang Yanyan, 2007).

Although the three typical opinions above are somehow rational, according to Prof. Wu, both researchers and the SPC misunderstand the collective disputes in China. Prof Wu sorts the collective disputes into 5 types: labor disputes, real estate disputes, farming disputes, securities disputes and mass tort/contract disputes. In dealing with these 5 types of the disputes, different kind of pressure may be caused by: lack of enough judicial power, judicial inability or short of judicial technique. The SPC should make a difference between collective disputes and corresponding judicial policies. The SPC now try to establish a uniform policy to handle different collective disputes, which neither resolve disputes nor help to release the courts' pressure in dealing with the dramatic increase cases. Only by telling the difference between types of the collective disputes can the research helps to perfect the collective litigation in China (Wu Zeyong, 2008, P.145-151).

The scholars' opinions seem against each other, however they all agree that the SPC's refusal to the representative litigation is unjustified. The key difference between scholars is what type of resolution should the SPC choose to deal with the collective disputes. Apparently, Prof. Fan is for the ADR, while others believe the representative litigation should play a more important role, and the policy of the SPC makes the hindrance.

Since the publication of Prof. Fan's On ADR advocating the merits of the ADR which have been forgotten as Chinese over-dedicate to building a formal litigation procedure system, Chinese traditional dispute resolution "People's Mediation"(Renmin Tiaojie) meets its good chance to revive. From then on China has moved to the wave of ADR movement, and the SPC could not out of this movement. However, China could not pay much more attention to the alternative dispute resolutions.

In a newly published monograph, Prof. Fan systematically study recent dispute resolutions in China. She sings high to the mediation, as she always does (Fan Yu, 2007). However, Prof. Fan goes too far. She overpraises the function of the mediation in disputes resolution: litigation procedure seems to be secondary when it comes to building multiple dispute resolutions. For the sake of easing burden of the courts, Prof. Fan is quite right, as China has a strong tradition to mediation and hundreds of Peolple's Mediation Committees need cases to be settled to revive. However, Prof. Fan overlooks the fact that too much ADR may reduce the function of civil procedure where law is well implemented. In the mediation, "consent is often coerced; the bargain may be struck by someone without authority; the absence of a trial and judgment renders subsequent judicial involvement troublesome; and although dockets are trimmed, justice may not be done. Like plea bargaining, settlement is a capitulation to the conditions of mass society and should be neither encouraged nor praise."(Owen Fiss, 1984, P. 1075) China now has reached the peak of the ADR-advocacy movement, and it is time to stay calm to rethink about what kind of cases are fit for settlement and what for judgment. "Two tracks" may be simple to understand the dispute resolutions, however, I would like to include those cases in which there are significant distributional inequalities; those in which it is difficult to generate authoritative consent because organizations or social groups are parties or because the power to settle is vested in autonomous agents; those in which the court must continue to supervise the parties after judgment; and those in which justice needs to be done, or to put it more modestly, where there is a genuine social need for an authoritative interpretation of law (Owen Fiss, 1984, P. 1078).

It should be mentioned that, the ADR movement in USA or European countries is totally different from China. As those countries have already had their formal and well-functioned litigation procedures, the civil procedure in China is too young and just starts to gain its weight. However, the fast growing informal mediation-type resolution may steal the thunder in cases where the civil procedure should play its role.

\section{New Development: Alternative Resolutions}

The SPC may not be willing to see the increase of the collective litigation, however, collective struggle has moved to the courts. The administrative bodies still want to control the disputes resolutions, but the influence continues to decrease. For example, the number of disputes handled by the government-backed "People's Mediation" has dramatically decreased from 7,919,506 in 1980 to 5,433,319 in 2004 (Wang Jue, 2005). However, the governments still hope to resolve most disputes (Stanley B. Lubman, 1996, P.82, 96). In recent years, when it comes to the collective 
disputes, both the government and courts have tried their efforts to settle them.

\subsection{Mediation}

ADR movement prevails inside and outside the courtrooms. The traditional type of disputes resolution has now come to rebound. There has been a significantly increased emphasis on using judicial mediation to resolve multiple party disputes recently, especially when Chinese are endeavored to a harmonic society under the slogan of "Making a Harmonic Society"'(Goujian Shehui Zhuyi Hexie Shehui).

\subsection{1 outside the courtrooms: People's Mediation (Renmin Tiaojie)}

In contrast to many nations that have collective litigation, China has a strong collective tradition. Disputes have often been resolved collectively and informally (Lester Ross, 1990, P. 15). Additionally, Chinese courts have historically been inhospitable for adjudicating individual rights (Lester Ross, 1990, P. 16, 17), and individuals are often reluctant to use the courts (Albert H. Y. Chen, 2004).

In China, the People's Mediation Committees (PMCs) are, with courts, the most widely known dispute resolution institutions. People's Mediation has been frequently used in China, and is honored with the name of "Oriental Flower" (Dongfang Yizhi Hua). It is clear that the People's Mediation occupies a major place among different dispute resolutions. Although the People's Mediation is not used as frequently as it used to be (Fu Hualing, 1992), it rebounds when Chinese leaders find that the People's Mediation contains more harmonic elements than the litigation. Corresponding rules are made to encourage the use of the People's Mediation, such as "Opinions on Improving the People's Mediation" (Guanyu Jingyibu Jiaqiang Xinshiqi Renmin Tiaojie Gongzuo de Yijian), "Provisions on Hearing Civil Cases involving the People's Mediation Agreement"(Guanyu Shenli Sheji Renmin Tiaojie Xieyi de Minshi Anjian de Ruogan Guiding), "Provisions on the People's Mediation" (Renmin Tiaojie Gongzuo Ruogan Guiding), "Opinions on Improve the People's Mediation For Social Stability" (Guanyu Jinyibu Jiaqiang Renmin Tiaojie Gongzuo, Qieshi Weihu Shehui Wending de Yijian), "Opinions on Further Improving the People's Mediation"(Guanyu Jinyibu Jiaqiang Xinxingshixia Renmin Tiaojie Gongzuo de Yijian). The most important rules are an SPC normative provision in 5 September 2002 — "Provisions on Hearing Civil Cases involving the People's Mediation Agreement"(Guanyu Shenli Sheji Renmin Tiaojie Xieyi de Minshi Anjian de Ruogan Guiding) and "Provisions on the People's Mediation"(Renmin Tiaojie Gongzuo Ruogan Guiding) by Justice Department in 11 September 2002.

These two provisions primary aimed at improving the status of the People's Mediation. The legal effect of the mediated agreement and the mediation procedure are the key parts. Both the SPC and the Justice Department explicitly state that the mediated agreement has preferential effect: the legal effect will be affirmed by the courts once the mediation procedure is legitimate. Previously, settlements reached through other mediation institutions were said to have no binding legal effect. It may simply mean that mediated agreements were just a contract between two parties, and parties could at any time deny the agreement and sued to court for a hearing on the merits as if the mediated agreement was not a result of resolution.

No official statistics are available as to the exact proportion of multiparty disputes resolved through People's Mediation. However, some empirical evidence indicating the important role of the People's Mediation has played in dealing with the collective disputes can be obtained (Hu Dongping, 2006). In Ningbo Zhejiang province, the People's Mediation Committees successfully mediated nearly 1,000 collective disputes, $75 \%$ of total number.

Many articles have provided a specific list of the virtues of mediation, such as: it has the flexibility needed to deal with cases where there are gaps between the law and the reality, it simplifies judicial procedure for the masses and decreases the backlog of cases in the courts, it gives the greatest possible control to the parties over their own rights and interests, and it provides a settlement that is relatively easy to implement because it is based on the agreement of the parties. But I would like to say that, most important of all, "Mediation" literally fits for the Chinese, especially the leaders' taste of harmony. China always takes the "Litigation" as a have-to device---- only when alternative resolutions can not get the dispute resolved will people resort to court (Neil Diamant, 2000, P. 541).

Recently, however, Chinese legal scholars have begun to question those rosy views of mediation. Some argue that the emphasis on mediation has led to a denial of proper remedies to those whose rights have been infringed. Courts spend an inordinate amount of time attempting to mediate cases that should simply be adjudicated and dispensed with. Thus, it may not even be true that mediation reduces the load on courts (Ji Weidong, 1989). Some criticize that mediation for often failing to tell right and wrong in disputes and only coming up with muddled settlements not based on parties' clear understanding of the facts and the law. This type of mediation is criticized as "out-of-precedure" mediation (Zheng Qixiang, 1990, P. 26-28). Meanwhile, the expandability of the jurisdicition of the PMCs, from the ordinary civil disputes to some complex or even collective ones worries the scholars a lot (Zhou Yongkun, 2007): the PMCs are often unable or unwilling to enforce legal standards; the mediators may simply lack the education necessary to do the job competently (Yang Yulin, 2005). Mediators' ignorance of the law particularly devastates the collective disputes resolution system, and the function of adjudication. As Prof. Fiss said in his Against Settlement, the purpose of 
adjudication should be understood in broader terms. Adjudication uses public resources, and employs not strangers chosen by the parties but public officials chosen by a process in which the public participates. These officials, like members of the legislative and executive branches, possess a power that has been defined and conferred by public law, not by private agreement. Their job is not to maximize the ends of private parties, nor simply to secure or break the peace, but to explicate and give force to the values embodied in authoritative texts such as the Constitution and statutes: to interpret those values and to bring reality into accord with them. This duty is not discharge when the parties settle in heavy mediation-apt air (Owen Fiss, Against Settlement, 1984, P.1805).

\subsubsection{Inside the courtrooms: Susong Tiaojie (Court Mediation)}

Court Mediation is always the preference of the Chinese legislators. The 1982 CPL instructed that mediation should be "emphasized" (zhuozhong tiaojie); when attempts at mediation failed, they were to proceed to adjudication (Art. 61982 CPL). Art. 9 CPL stated that the People's Courts should conduct mediation in accordance with the principles of voluntariness and lawfulness.

According to the CPL, the mediation agreement has the same effect as a court judgment, once it is serviced to the parties. In fact, judges may incline to mediation rather than the adjudication as mediation agreement may hardly be appealed-only when the mediation violates principles of voluntariness and lawfulness can the retrial process get started (Art. 182, CPL) - therefore, judges may no fear of being overruled by higher courts, which may seen as a threat to his career. The fact is that, to prove such violation is a very hard job, as the mediation itself is not as formal as the adjudication. Procedural rules in mediation may not be complied with (Palmer Michael, 1989, P. 145).

The SPC has in many times shows its preference in some judicial interpretation on the Court Mediation in handling the collective disputes, and the Court Mediation has met its rebound in 2004 (Figure 1). In the 2002 Provisions mentioned above, Art 4, the SPC instructs the People's Court, as a principle, should stress mediation and encourage the parties to reach reconciliation. So is another SPC normative document in March 2007, "Several Opinions Regarding Further Improving the Positive Roles Judicial Mediation Plays in the Construction of Socialist Harmonious Society" (2007 Opinions) (Guanyu Jinyibu Fahui Susong Tiaojie zai Goujian Shehui Zhuyi Hexie Shehui zhong Jiji Zuoyong de Ruogan Yijian), which speaks highly of the importance of the Court Mediation in building a harmonic society. While the 2007 Opinions leaves much room for the courts to innovate the Court Mediation mechanism, the SPC emphasizes that, court mediation should be firstly considered when it comes to certain types of civil cases. Art. 5 of 2007 Opinions demands that courts should focus on, among other things, mediating joint litigation and group litigation and those cases involving collective interests.

The same as the People's Mediation, no official statistics are available as to the exact proportion of multiparty disputes resolved through mediation by the courts across the country. However, as most of the collective disputes are accepted by the basic courts, percentage of mediation when the Basic People's Courts handle multiparty disputes may fairly tell the truth that the Court Mediation is clearly a dominant technique for multiparty disputes. In Chongwen District Basic People's Court, Beijing, for example, the proportion of multiparty cases resolved by mediation has increased from $64 \%$ in 2003 to a claimed $92.4 \%$ in 2005 (Table 1). Table 2 illustrates the percentage of mediation in different types of multiparty civil suits (Michael Palmer and Chao Xi, 2007).

\subsection{Litigation: Test Case}

As mentioned above, lawsuits filed by hundreds or thousands of plaintiffs against the same defendant(s) can paralyse entire courts complately. The Daqing Lianyi Case is a good example. The court ordered the attorney of the plaintiffs to divide the collective litigation into several tiny cases with each 10 plaintiffs at most. Although the representative litigation could somehow pool the plaintiffs' interests effectively, judges still face heavy pressure when hear such cases with so many parties. Actually speaking, the courts must consider collective cases as a multitude of individual cases each plaintiff has a number of procedural rights, is entitled to be heard and may participate personally in the hearings.

Like the other types of collective litigation in some countries, the most prevalent characteristic of the collective disputes is that all cases are based on more or less the same facts and legal issues. Thus, it would be sufficient to solve this issue once and for all cases, if a court decision were binding for all plaintiffs. Hence the question is how to deal efficiently with a great number of lawsuits based on the same matter. Theoretically, while one of the answers to the question is to pool all the plaintiffs' interests in a case by allowing a group litigation or representative litigation, the other answer would be a test case, which allow the court to focus on a two-party-litigation (one plaintiff, one defendant) and the outcome of the test case will be binding for all other plaintiffs.

So far there are no provisions on the Test Case in China, however, the courts have amazing wisdom when dealing with the collective litigation, which I call it "Pick one for Trial" (Fenbie Li'an, Xianxing Shenli).The court would firstly instruct the multiparty to bring their own case individually, and then choose one or several typical suits from these individual cases which have the same fact or legal issues. Such case(s) is the test case: the decision to it will bind other collective disputes, or at least has influence on the other cases. When the test case(s) is (are) heard, other plaintiffs or 
potential parties intend to bring their cases usually pay attention to the test case(s).

The Test Case mechanism has already successfully played its role in collective disputes, especially in the fields of labor disputes, real estate disputes, stock disputes and so on (Zhang Wusheng, 2007, P.447-448). In the Daqing Lianyi Case the courts pick up 24 cases as the test cases. All the plaintiffs get compensations. Another typical case is the Zhujiang Oasis Case (Zhujiang Lüzhou An), where Test Case mechanism is applied by the Chaoyang District Court, Beijing. Tens of owners sued the seller for breach of faith not offering municipal water pipe and electricity and claimed damages. The court picked up one case for trial and the judgment has domino-effect in the following hearing (Xiao Jianguo, 2007, P.136).

The Test Case mechanism has released much pressure of the courts in China. Still questions are waiting to be solved. Some of them are: not even all other cases could embracing res judicata effect to the test case judgment, as the individual claim may be different; the judgment of the test case has binding effect to the following cases is counter to the Due Process Principle - Nobody can be subject to the binding force of a court judgment unless he or she had the right to participate in the proceedings, to attend the hearings, to present facts, evidence and legal arguments to the courts.

\section{Conclusion}

Different impediments have barred the road for the collective litigants' access to the court. These impediments may be from the SPC, the local courts, or from the government. From the People's Court's aspect, collective litigations tend to place significant pressures on the Chinese courts. The latter have generally found it difficult to establish autonomy and authority in the shadow of the leadership of Communist Party. Collective actions are sometimes problematic to the leadership, because they may carry significant political overtones. A collective suit may involve, on one hand, a politically well-connected local entity, and on the other, hundreds of distressed and aggrieved claimants who are prepared to protest on the street if the judgment is for the defendant. Collective action has indeed become a very powerful weapon for powerless civilians to improve their welfare (Kevin Latham, 2006, P. 56, 76). In that case, political ramifications of the collective litigation weigh heavily on the courts' mind. The SPC and some local Chinese courts are strongly averse to politically sensitive cases or force the parties into mediation, disregarding how long the judicial process would tend to be prolonged.

Many press accounts of collective actions have noted the role such cases play in raising the legal awareness of both the litigants and society. The filing of a collective action may at times be sufficient to attract the interest of higher-level authorities, or simply to pressure local officials and courts. Collective litigation may also force society to confront cases and areas of law that might otherwise be ignored. Thus collective litigation is more influential than other forms of litigation. Both the SPC and the Government seem not pleased with the increase of the collective litigation. However, that the plaintiffs increasingly using law (through litigation) to pursue their own interests and to force government pay more attention to their welfare, will further promote the improvement of the collective litigation mechanism, and the evolution of the state's approach towards rule of law in China.

Acknowledgement: Renmin university of China has funded the research (Project No. 22386030).

\section{References}

Jiang, Wei \& Jia, Changcun. (1989).Lun Jituan Susong (Xia). Zhongguo Faxue, p.103,110.

Zuigao Renmin Fayuan. (1986). Anyue Xian Yuanbao Xiang, Nuli Xiang 1569 hu Daozhong Jingying Hu yu Anyue Xian Zhongzi Gongsi Shuidao Zhizhong Gouxiao Hetong Jiufen An. Zuigao Renmin Fayuan Gongbao.

Jiang, Wei \& Jia, Changcun. (1989).Lun Jituan Susong (Xia). Zhongguo Faxue, p.110-111.

Tang, Dehua (ed.).(1991). Xin Minshi Susong Fa Tiaowen Shiyi. Beijing: Renmin Fayuan Publisher, p.105.

Jiang, Wei \& Xiao, Jianguo. (1994). Guanyu Daibiaoren Susong De Jige. Wenti. Faxue Jia. p.3-4.

Zhang, Weiping. (2000).Susong Goujia yu Chengshi: Minshi Susong de Fali Fenxi. Beijing: Tsinghua University of China, p. 362-363.

Fan, Yu. (2005). Jituan Susong Wenti Yanjiu. Beijing: Peking University of China, p. 25-26.

Li, Guoguang \& Jia, Wei. (2003).Zhengquan Shichang Xujie Chengshu Minshi Peichang Zhidu. Beijing: Law Press, p. 21-22.

Jiang, Wei (ed.). (2005).Minshi Susong Fa Zhuanlun. Beijing: Renmin University of China Publisher, p.113-114.

Zhang, Wusheng \& Yang, Yanyan. (2007). Woguo Qunti Susong de Lifa yu Sifa Shijian. FAXUE YANJIU.

Michael Palmer \& Chao Xi. (2007). National Report: Collective and Representative Actions in China. [Online]. Available: http://www.law.stanford.edu/display/images/dynamic/events_media/China_National_Report.pdf (Dce. 15, 2009) 
Li, Guoguang \& Jia, Wei. (2003).Zhengquan Shichang Xujie Chengshu Minshi Peichang Zhidu. Beijing: Law Press, p. 295-296.

Ji, Min. (2006). Gaige Minshi Gongtong Susong Anjian Shouli Fangshi, Fahui Renmin Fayuan Zai Goujian Hexie Shehui zhong de Baozhang Zuoyong. Renmin Sifa.

Zhang, Wusheng \& Yang, Yanyan. (2007). Woguo Qunti Susong de Lifa yu Sifa Shijian. FAXUE YANJIU, p. 118.

Linda Silberman. (1999). The Vicissitudes of the American Class Action- With a Comparative Eye, 7 Tulane Journal of International \& Comparative Law .201.

Theodore Eisenberg \& Geoffrey P. Miller. (2004). Attorney Fees in Class Action Settlements: An Empirical Study, $1 \mathrm{~J}$. Empirical Legal Study, 27, 51-54.

Deorah R. Hensler. (1999). Pursuing Public Goals for Private Gain, Executive Summary, Class Action Dilemmas, (Santa Monica, CA: Rand Institute for Civil Justice.20.

Benjamin Liebman. (1998). Class Action Litigation in China. Harvard Law Review.

Banjimin L. Liebman. (1999). Legal Aid and Public Interest Law in China. Texas International Law Journal.

$\mathrm{Fu}$, Yulin. (2002). Qunti Xin Jiufen de Sifa Jiuji.[Online]. Available: http://law.chinalawinfo.com/newlaw2002/SLC/slc.asp?gid=335571324\&db=art (Dec. 15, 2009)

Donald C. Clarke. (1996). Power and Politics in the Chinese Court System: The Enforcement of Civil Judgments. COLUM. J. ASIAN L.

Fan, Yu. (2005). Jituan Susong Wenti Yanjiu. Beijing: Peking University of China, p. 450-451.

Fan, Yu. (2007) Jiufen Jiejue de Lilun yu Shijian. Beijing: Peking University of China.

Zhang, Wusheng \& Yang, Yanyan. (2007) Woguo Qunti Susong de Lifa yu Sifa Shijian. FAXUE YANJIU.

Wu, Zeyong. (2008).Qunti xin Jiufen de Goucheng yu Fayuan Sifa Zhengce de Xuanze. Falü Kexue, p.145-151.

Michael Palmer \& Chao Xi. (2007). National Report: Collective and Representative Actions in China. [Online]. Available: http://www.law.stanford.edu/display/images/dynamic/events_media/China_National_Report.pdf (Dce. 15, 2009)

Sanlu Naifen Shijian Zhiyuan Lüshituan Gongzuo Jianbao.[Online.] Available: http://www.gyflr.org/article.asp?id=521 .

Owen Fiss.(1984).Against Settlement, 93 Yale Law Journal.1075

Wang, Jue. (2005). Jianlun Renmin Tiaojie Lifa de Shijian Jichu. Zhongguo Sifa, p.50-51.

Anthony R. Dicks. (1996). Compartmentalized Law and Judicial Restraint: An Inductive View of Some Jurisdictional Barriers to Reform. In Stanley B. Lubman (Eds.). China's Legal Reforms. Oxford: Oxford University Press, p. 82, 96.

Lester Ross. (1990).The Changing Profile of Dispute Resolution in Rural China: The Case of Zouping County, Shangdong. STAN. J. INT'L L..

Lester Ross. (1990).The Changing Profile of Dispute Resolution in Rural China: The Case of Zouping County, Shangdong. STAN. J. INT'L L., p. 16-17.

Albert H. Y. Chen. (2004). An Introduction to the Legal System of The People's Republic of China (Third Edition). HK: Butterworths.

Fu, Hualing. (1992).Understanding People's Mediation in Post-Mao China. Journal of Chinese Law.

Hu, Dongping, (2006). Shilun Quntixing Jiufen Jiejue zhong Renmin Tiaojie Chengxu de Yinru .Zhongguo Sifa, p.18-19.

Neil Diamant.(2000). Conflict and Conflict resolution in China: Beyond Mediation-Centered Approaches, The Journal of Conflict Resolution, Vo. 44, No. 4. 541.

Ji, Weidong. (1989).Fazhi yu Tiaojie de Beilun. Faxue Yanjiu, p.21, 22.

Zheng, Qixiang et al. (1990). Zhuozhong Tiaojie de Tifa Ying Yu Xiugai.Faxue,p. 26-28.

Zhou, Yongkun. (2007). Lun Qiangzhixing Tiaojie dui Fazhi he Gongping de Chongji . Falü Kexue.

Yang, Yulin. (2005).Guifan Renmin Tiaojie Xieyi Tigao Renmin Tiaojie Gongzuo Shuiping . Zhongguo Sifa, p. 53-54.

Michael Palmer \& Chao Xi. (2007). National Report: Collective and Representative Actions in China. [Online]. Available: http://www.law.stanford.edu/display/images/dynamic/events_media/China_National_Report.pdf (Dce. 15, 2009).p.12-13. 
Michael Palmer. (1989). The Revival of Mediation in the People's Republic of China: (2) Judicial Mediation, Yearbook on Socialist Legal Systems.145-171.

Zhang, Wusheng. (2007). Lun Qunti Susong de Biaoxian Xingshi. Zhongwai Faxue, p 447-448.

Xiao, Jianguo. (2007). Minshi Gongyi Susong Moshi Yanjiu. Zhongguo Faxue, p. 136.

Michael Palmer. (2006). The Emergence of Consumer Rights: Legal Protection of the Consumer in the PRC. In Kevin Latham \& Stuart Thompson et al. (Eds.). Consuming China: Approaches to Cultural Change in Contemporary China. London and New York: Routledge, p. 56, 76.

Table 1. Concluded Multiparty Civil Suits in Chong Wen District People's Court, Beijing: Mediation v. Judicial Decision

\begin{tabular}{|l|l|l|l|l|l|l|}
\hline Year & $\begin{array}{l}\text { Concluded } \\
\text { Multiparty } \\
\text { Litigation } \\
\text { Cases }\end{array}$ & $\begin{array}{l}\text { Cases } \\
\text { Resolved } \\
\text { by } \\
\text { Mediaton }\end{array}$ & $\begin{array}{l}\text { Cases } \\
\text { Withdrawn } \\
\text { Following } \\
\text { Mediaiton }\end{array}$ & $\begin{array}{l}\text { Percentage } \\
\text { of Mediated } \\
\text { Cases }\end{array}$ & $\begin{array}{l}\text { Cases } \\
\text { Resolved by } \\
\text { Adjudication }\end{array}$ & Percentage \\
\hline 2003 & 643 & 238 & 174 & 64 & 231 & $36 \%$ \\
\hline 2004 & 679 & 213 & 229 & 65 & 237 & $35 \%$ \\
\hline 2005 & 3705 & 472 & 2952 & 92.4 & 281 & $7.60 \%$ \\
\hline
\end{tabular}

Table 2. Percentage of Mediation in Different Types of Multiparty Civil Suits.

\begin{tabular}{|l|l|l|l|}
\hline Type & $\begin{array}{l}\text { Number of } \\
\text { Multiparty } \\
\text { Suits }\end{array}$ & $\begin{array}{l}\text { Mediated } \\
\text { Suits }\end{array}$ & $\begin{array}{l}\text { Percentage } \\
\text { Mediated }\end{array}$ \\
\hline Heating Supply Disputes & 395 & 355 & $90 \%$ \\
\hline Labor Disputes & 41 & 31 & $76 \%$ \\
\hline Rental Disputes & 64 & 42 & $65.60 \%$ \\
\hline Real Estate Contract Disputes & 146 & 6 & $4 \%$ \\
\hline Reputation Disputes & 8 & 8 & $100 \%$ \\
\hline Property Disputes & 52 & 28 & $54 \%$ \\
\hline Loan Contract Disputes & 2689 & 2618 & $97 \%$ \\
\hline Demolition Disputes & 13 & 8 & $62 \%$ \\
\hline Sales Contract Disputes & 191 & 160 & $84 \%$ \\
\hline Insurance Contract Disputes & 327 & 17 & $5 \%$ \\
\hline Processing Contract Disputes & 5 & 5 & $100 \%$ \\
\hline
\end{tabular}

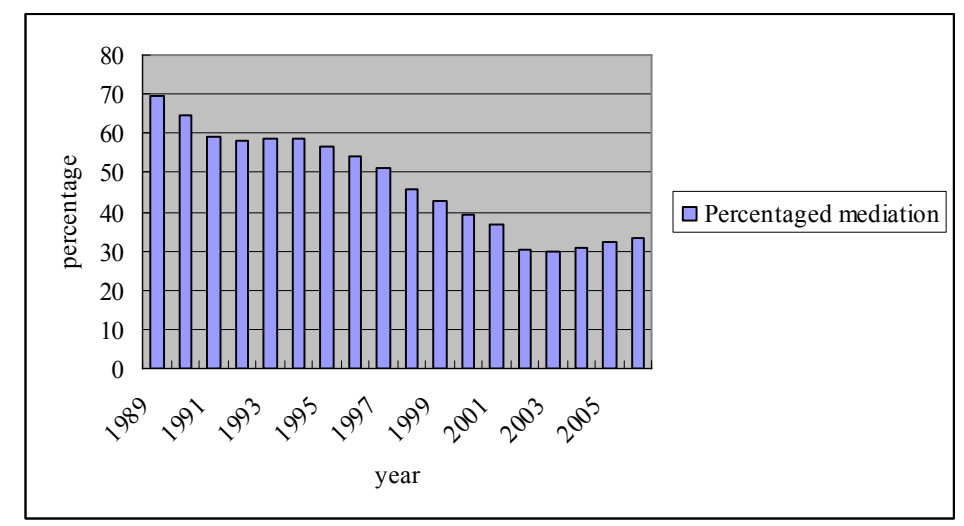

Figure 1. Percentage of Court Civil Suits Mediation in the First Instance across China 